\title{
Morphology and pathogenicity of Rhizoctonia solani Kühn associated with potato black scurf in Nariño (Colombia)
}

\section{Morfología y patogenicidad de Rhizoctonia solani Kühn asociado con la costra negra de la papa en Nariño (Colombia)}

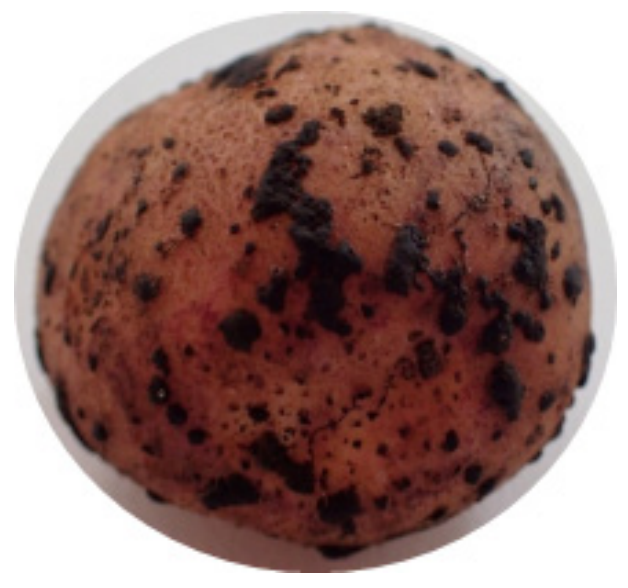

CARLOS A. BETANCOURTH-GARCÍA ${ }^{1-4}$

BERTHA LUCIA CASTRO-CAICEDO²

CLAUDIA QUIROZ-OJEDA

BENJAMIN SAÑUDO-SOTELO²

CARLOS FLOREZ-CASANOVA ${ }^{3}$

CLAUDIA SALAZAR-GONZALEZ ${ }^{1}$

\section{Solanum tubersoum var. Red tubers with black scurf caused by Rhizoctonia solani.}

Photo: B.L. Castro

\begin{abstract}
The objective of the research was to understand the diversity of Rhizoctonia solani in potato crops in Nariño. Tubers with sclerotia were collected from farms in the municipalities of Pasto, Ipiales, Tuquerres and Ospina. In a laboratory, the strains were grouped in categories, selecting 30 for morphological and pathogenic studies. In an PDA medium, the daily mycelia growth rate (DMGR), pigmentation, texture, growth pattern (GP) and sclerotia characteristics were determined. The hyphae width and nuclei number were also evaluated. Solanum tuberosum L. Group Phureja seedlings were used in the pathogenicity test. Initially, 494 strains were obtained with diverse cultural characteristics, grouped in 15 categories, selecting two of each one for the research. Of the 30 strains, there were significant differences in the DMGR according to the Tukey test $(P=0.05), 96.6 \%$ of the strains had an average of $16.6 \mathrm{~mm}$ day ${ }^{1} .15$ day-old colonies had cream, beige, brown and salmon colors. $95 \%$ of the isolates formed plush mycelium with GP concentric simple rings, complex rings, and scattered and stellate forms. Sclerotia formation began at 6 days (average), and, at 15 days, dispersed arrangement predominated, as well as a peripheral, with brown, beige and cream colors. Three isolates did not produce sclerotia. The hyphae had a mean of $9.7 \mu \mathrm{m}$, and the nuclei number ranged between $7.2-8.2$, without statistical differences. Twenty-four isolates caused $100 \%$ plant infection. The results suggest differences between the isolates, associated with levels of pathogenicity or anastomosis groups (AG), characteristics that will be studied in future research.
\end{abstract}

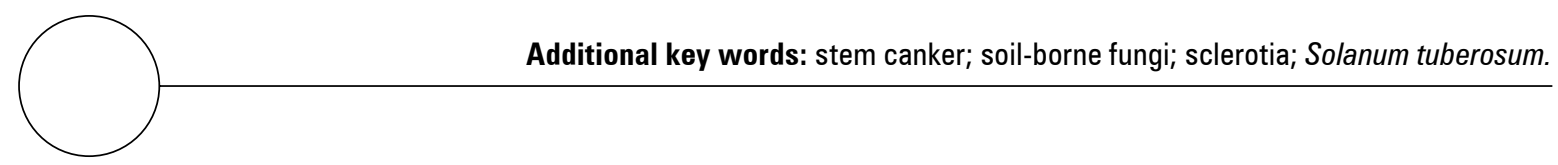

Universidad de Nariño, Faculty of Agricultural Science, Research Group of Plant Health, Pasto (Colombia). ORCID Betancourth-García, C.A.: 0000-0001-6573-4230; ORCID Quiroz-Ojeda, C.M.: 0000-0002-0676-7427; ORCID Salazar-González, C.E.: 0000-0002-5461-2761

2 External Consultant, Pasto (Colombia). ORCID Castro-Caicedo, B.L.: 0000-0003-3207-1834; ORCID Sañudo-Sotelo, B.A.: 0000-0001-9943-5650

Support Researcher, Pasto (Colombia). ORCID Florez-Casanova, C.A.: 0000-0003-1626-5727

4 Corresponding autor. cbet79@yahoo.com 


\section{RESUMEN}

El objetivo de la investigación fue conocer la diversidad de Rhizoctonia solani en cultivos de papa en el departamento de Nariño. Se colectaron tubérculos con esclerocios en fincas de los municipios de Pasto, Ipiales, Túquerres y Ospina. En laboratorio, los aislamientos se agruparon en categorías, seleccionando 30 para los estudios morfológicos y patogénicos. En medio PDA, se determinó la tasa diaria de crecimiento micelial (TDCM), color, textura, patrón de crecimiento (PC) y características de los esclerocios. Se evaluó ancho de hifas y número de núcleos. Para pruebas de patogenicidad se utilizaron plántulas de papa Solanum tuberosum L. Group Phureja. Se obtuvieron 494 aislamientos con características culturales variadas, agrupados en 15 categorías, seleccionando dos de cada grupo para la investigación. Los 30 aislamientos mostraron diferencias significativas en la TDCM y según prueba de Tukey $(P=0,05 \%)$, el 96,6\% tuvo un promedio de 16,6 $\mathrm{mm} \mathrm{día}^{-1}$. Colonias de 15 días de edad presentaron colores crema, beige, marrón y salmón. El 95\% de los aislamientos formaron micelio afelpado con PC radial simple, radial complejo, disperso y estrellado. La formación de esclerocios se inició a los 6 días y a los 15 mostraron disposición dispersa y periférica, con colores marrón, beige y crema. Tres aislamientos no produjeron esclerocios. El ancho de hifas tuvo un promedio de 9,7 $\mu \mathrm{m}$ y entre 7.2-8.2 núcleos, sin diferencias estadísticas. Veinticuatro aislados causaron $100 \%$ de infección en las plantas. Los resultados sugieren diferencias entre aislamientos, asociados con patogenicidad o grupos de anastomosis, características que serán estudiadas en futuras investigaciones.

Palabras clave adicionales: cancro de tallo; hongos del suelo; esclerocios; Solanum tuberosum.

Received: 01-10-2020 Accepted: 27-11-2020 Published: 06-01-2021

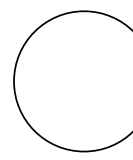

\section{INTRODUCTION}

In the Nariño Department, potato production ranks third in Colombia, and 24,906 ha were planted in 2019 , with a yield average of approximately 578,695 $t$ (FEDEPAPA, 2019). The many phytosanitary problems that affect potato cultivation include the black scurf and stem canker caused by the fungus Rhizoctonia solani Kühn (Tsror, 2010; ICA, 2011; ÁlvarezSánchez et al., 2018). Rhizoctonia solani causes damage in all stages of potato development crops, including emerging shoots, young neck tissues of the seedlings, roots and stolons, where necrotic brown lesions can strangle them. In adult plants, necrotic lesions interfere with the normal movement of nutrients, inducing the formation of aerial tubers in the axils of the leaves. Developing tubers remain small or deformed, and the surface of tubers have black crusts or sclerotia, detracting from quality (Tsror, 2010; ICA, 2011). Worldwide, this disease causes important decreases in yield and quality and is responsible for losses of up to US\$ 75 million/year in several countries (Das et al., 2014).

The fungus $R$. solani (anamorph of Thanatephorus cucumeris (Frank.) Donk) belongs to Class Basidiomycetes. The hyphae are dark brown, septate and multinucleated, where cells have 2-18 nuclei (Misawa and Kurose, 2018, 2019). The hyphae fusion, known as anastomosis, is a particular characteristic of this species (Carling, 1996). This condition has been considered for classification in anastomosis groups (AGs), which differ from each other in phylogenetic, morphology, physiology and pathogenicity (Fiers et al., 2011; Ferrucho et al., 2012; Muzhinji et al., 2015). To date, 13 AGs has been identified worldwide, and the more important are AG3 and AG4. AG3 is the most pathogenic and is characterized mainly by the formation of sclerotia on tubers (Ferrucho et al., 2012; Das et al., 2014; Muzhinji et al., 2015). In Venezuela, Ecuador and Colombia, AG3 has been determined as the most pathogenic in potato cultivars (Escalona et al., 2011; Alban, 2015; Ferrucho et al., 2012, 2013).

The study of population genetics of plant pathogens is useful for understanding epidemiology, ecology and evolutionary trajectory to effectively estimate the pathogen potential evolution and dispersion under natural ecosystems. This knowledge evaluates the sensitivity of pathogen isolates for agrochemicals and development of resistant cultivars (Zhan, 2016; Chañag et al., 2018). Because of the importance of $R$. solani in potato production in the Nariño Department, the objective of this research was to obtain a 
preliminary identification and characterization of $R$. solani populations in the region. The following studies expand knowledge of this pathogen and evaluate management strategies.

\section{MATERIALS AND METHODS}

\section{Sampling and isolation of $R$. solani}

The sample collection was done from September to November, 2019, on commercial potato farms in the municipalities of Pasto, Ipiales, Tuquerres and Ospina, south of Colombia (1'12' $\mathrm{N}$ and $77^{\circ} 16 \mathrm{~W}$ to $0^{\circ} 49 \mathrm{~N}$ and $77^{\circ} 38^{\prime} \mathrm{W}$ ), at altitudes of 2,915 to 3,179 $\mathrm{m}$ a.s.l. The laboratory work was carried out in the phytopathology laboratory of the Faculty of Agricultural Sciences of the Universidad de Nariño (Pasto, Colombia), with an altitude of 2,527 $\mathrm{m}$ a.s.1. In each municipality, potato crops in the harvest stage were randomly selected, collecting 10 tubers with sclerotia/place. The sclerotia were removed using a scalpel, disinfested with sodium hypochlorite (3\%), placed on potato dextrose agar (PDA) containing streptomycin sulphate $\left(20 \mathrm{mg} \mathrm{L}^{-1}\right)$, and incubated for $3 \mathrm{~d}$ at $25^{\circ} \mathrm{C}$, according Das et al. (2014) and Misawa et al. (2018). Rhizoctonia-like fungi colonies were identified according to Sneh et al. (1991), and the purification was done with the hyphal tipping technique on PDA.

\section{Morphological characterization of isolates}

The strains were grouped according cultural appearance, such as pigmentation, growth pattern (GP), and pattern of sclerotia formation (PSF), according Escalona et al. (2011) and Dubey et al. (2014). Of these groups, 30 strains were selected to continue the morphological study on PDA and incubation in dark for $15 \mathrm{~d}$ at $25^{\circ} \mathrm{C}$. Four repetitions were made for each isolate, placing $3 \mathrm{~mm}$ diameter plugs taken from the colony margins in the center of the plates. Strains were monitored daily for the following characteristics, according Dubey et al. (2014): - Mycelial growth, measuring the colony diameter ( $\mathrm{mm} /$ day), mean of two measurements; pigmentation, with evaluation at 8 and $15 \mathrm{~d}$, according to a color chart (Kramer, 2004); - mycelium texture: cottony (aerial mycelium), plush attached to the medium or grainy; - mycelial growth pattern (MGP) at $15 \mathrm{~d}$, classified according to Dubey et al. (2014) as: central, simple radial, complex radial, dispersed and star-shaped; - Sclerotia characteristics:
PSF, as peripheral, central, scattered, star-shaped or absent; size (using the software of imageJ program), categorized as microsclerotia $(<1 \mathrm{~mm})$ and macrosclerotia (>1 mm); shape (regular, irregular, globular and powdery); coloration and amount visually estimated. According to the sclerotia abundance, the isolates were classified as: 1-100 (scarce), 100-200 (moderate) and > 200 (abundant), as reported by Dubey et al. (2014).

The mycelial growth rate (MGR) was obtained in $\mathrm{mm}$ day $^{1}$ using the method of Dubey et al. (2014), and the data were subjected to ANAVA and Tukey's test $(P=0.05 \%)$. According to the MGR, the isolates were classified as: slow (10 $\mathrm{mm}^{2}$ day $\left.^{1}\right)$, medium (> 10-12 $\mathrm{mm}$ day $^{-1}$ ) and fast ( $>12 \mathrm{~mm}^{-1 a y^{-1}}$. With qualitative variables (pigmentation, mycelium texture, MGP and PSF), the averages of the proportion (\%) of isolates were obtained for each one.

Microscopic characteristics were made using method of Gondal et al. (2019); slides with mycelium printed with adhesive tape and stained with lactophenol blue $(0.05 \%)$ were used to observe the hyphal morphology of $R$. solani, (four plates/repetition) in 8-d-old cultures. The morphology of each culture was compared with previous descriptions, including width and length of the hyphal (Misawa et al., 2018). Number of nuclei per cell were counted by staining the hyphae with Safranin O + a drop of $3 \% \mathrm{KOH}$ on a portion of mycelium $48 \mathrm{~h}$ after incubation (Bandoni, 1979). Five observations of each characteristic/repetition were examined microscopically at $100 \mathrm{X}$. The data were subjected to ANOVA and Tukey's test $(P=0.05)$.

\section{Pathogenicity tests}

The inoculum was prepared by colonizing isolates of $R$. solani on rice grains for $18 \mathrm{~d}$ (Castro et al., 2013). Potato seedlings (S. tuberosum Group Phureja) sown in plastic cups (one tuber/cup) were used. The seedtubers were checked to be free of sclerotia and disinfested in water with 1\% sodium hypochlorite. Each cup contained $350 \mathrm{~g}$ of a soil-rice husk mixture (3:1), sterilized with hot water. Eighteen-day-old seedlings were inoculated with $6.0 \mathrm{~g}$ of rice colonized with each isolate; the inoculum was mixed in the upper $4 \mathrm{~cm}$ layer of the soil. Five plants were inoculated by strain, and a control free of pathogen was included. The plants were placed on tables under a mesh house, at $11-20^{\circ} \mathrm{C}$. Thirty-five days after inoculation, plant infection was evaluated, observing secondary 
symptoms (wilting and yellowing): lesions on roots, shoots, stolons or stem canker (primary symptoms). The results were expressed as a percentage of plants infected by isolate. Re-isolations of the pathogen were done to confirm the pathogenic nature of the isolates.

\section{RESULTS AND DISCUSSION}

\section{Sampling and isolation of $R$. solani}

The pathogen was $100 \%$ prevalent in all locations, where tubers with sclerotia were found, indicating the presence of this pathogen in the potato production area of the department. Out of the 50 samples, 17 were found in crops in Pasto, 12 in Ipiales, 9 in Tuquerres and 12 in Ospina. The commercial potato varieties with $R$. solani included the species $S$. tuberosum and S. tuberosum Group Phureja (Fig. 1). The sclerotia observed on the tubers had dark brown and black colors, with varied shape and size, from 1 to 4 $\mathrm{mm}$ in diameter, as reported by Misawa and Kurose (2018). From the sclerotia, 494 pure isolates were obtained with typical features of $R$. solani: hyphae with right-angle branches at the distal septae of cells, dolipore septum, and constriction at the branch, similar characteristics described by Sneh et al. (1991). No conidia or conidiophores were observed.

In this study, the pathogen sampling focused exclusively on the collection of tubers with sclerotia (Atkinson et al., 2010; Dubey et al., 2014; Muzhinji et al., 2015), or even from soil (Alban, 2015). The R. solani isolation from the sclerotia of commercial varieties of $S$. tuberosum, as reported by Escalona et al. (2011) for Venezuela, by Ferrucho et al. (2012) in Colombia, and, in Ecuador, by Alban (2015), obtained isolates from soil.

\section{Morphological characterization of isolates}

The 494 isolates showed diversity in pigmentation, GP and PSF at $15 \mathrm{~d}$ after incubation, as reported by Misawa and Kurose (2018). Predominantly white colonies and cream, light brown and salmon colors, with simple radial, complex radial and star-shapes were noticed. The sclerotia were arranged in the center, periphery, scattered or absent. These diversities
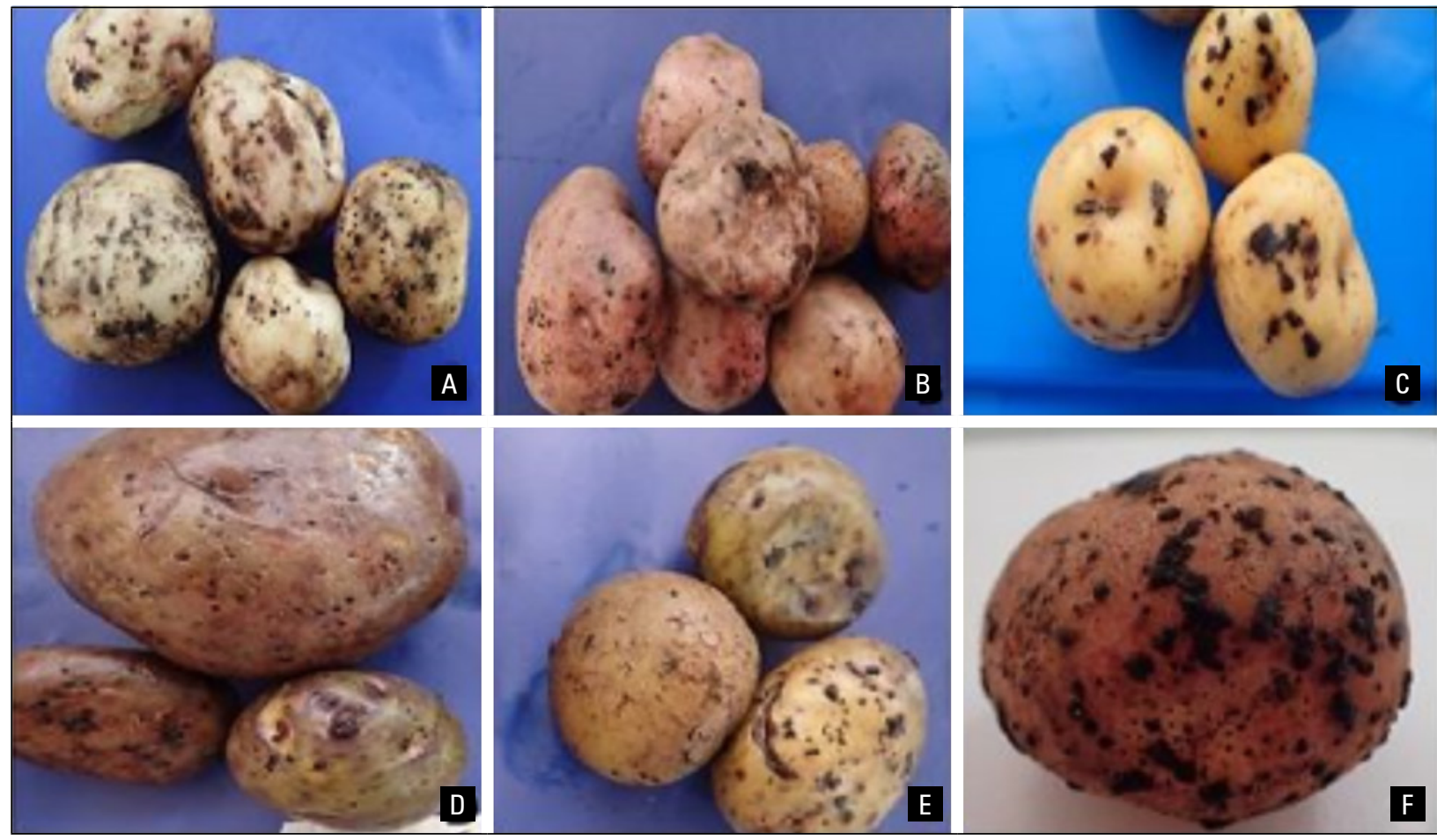

Figure 1. Potato tubers with $R$. solani sclerotia. A) Solanum tuberosum var. Unique, B) S. tuberosum var. Parda Suprema, C) $S$. tuberosum Group Phureja, D) S. tuberosum var. Diacol Capiro, E) S. tuberosum var. Superior and F) $S$. tuberosum var. Red Huila. 
coincide with several authors (Escalona et al., 2011; Oliveira et al., 2014; Abdel-Sattar et al., 2017), who suggested that such variability may be related to the culture medium, temperature, colony age, AG group or host plant species.
Based on the cultural features expressed by the R. solani isolates, 15 groups were classified, as shown in table 1. A variable number of isolates of each group were selected, with 30 isolates for the morphology and pathogenicity (Tab. 2).

\section{Table 1. Isolates of $\boldsymbol{R}$. solani grouped according cultural features in the PDA medium.}

\begin{tabular}{|c|c|c|c|c|}
\hline Group 1 & Group 2 & Group 3 & Group 4 & Group 5 \\
\hline $\begin{array}{l}\text { Plush and white mycelium } \\
\text { attached to the medium. } \\
\text { No sclerotia }\end{array}$ & $\begin{array}{c}\text { Plush and white mycelium } \\
\text { attached to the medium. } \\
\text { Late and white sclerotia } \\
\text { formation }\end{array}$ & $\begin{array}{l}\text { Plush and cream mycelium } \\
\text { attached to the medium, } \\
\text { with radial complex } \\
\text { circles. Central and brown } \\
\text { sclerotia }\end{array}$ & $\begin{array}{c}\text { Plush and salmon my- } \\
\text { celium, attached to the } \\
\text { medium, with simple radial } \\
\text { growth central and salmon } \\
\text { sclerotia }\end{array}$ & $\begin{array}{l}\text { Abundant cottony } \\
\text { mycelium, aerial, brown, } \\
\text { with complex radial } \\
\text { growth. Brown sclerotia } \\
\text { formation on the lid }\end{array}$ \\
\hline Group 6 & Group 7 & Group 8 & Group 9 & Group 10 \\
\hline $\begin{array}{l}\text { Pale salmon colony, } \\
\text { mycelium attached to the } \\
\text { medium. Scattered salmon } \\
\text { sclerotia }\end{array}$ & $\begin{array}{c}\text { Pale cream colony. Abundant } \\
\text { aerial mycelium. Scattered } \\
\text { white sclerotia }\end{array}$ & $\begin{array}{l}\text { Mycelium and sclerotia } \\
\text { brown, mostly central or } \\
\text { scattered }\end{array}$ & $\begin{array}{l}\text { White colony. Brown } \\
\text { sclerotia in radial growth, } \\
\text { towards the edge }\end{array}$ & $\begin{array}{l}\text { Pale salmon colony, } \\
\text { star-shaped growth. } \\
\text { Scattered and abundant } \\
\text { salmon sclerotia }\end{array}$ \\
\hline Group 11 & Group 12 & Group 13 & Group 14 & \\
\hline $\begin{array}{c}\text { Dark salmon colony, } \\
\text { sparse mycelium. Sclerotia } \\
\text { scattered, dark brown or } \\
\text { light brown }\end{array}$ & $\begin{array}{l}\text { Pale cream colony, with ra- } \\
\text { dial growth and wavy edges. } \\
\text { Cream sclerotia scattered } \\
\text { with gum exudates }\end{array}$ & $\begin{array}{c}\text { Cream and fluffy mycelium, } \\
\text { with wavy edges. Beige, } \\
\text { scattered and central } \\
\text { sclerotia }\end{array}$ & $\begin{array}{l}\text { Sparse and cream } \\
\text { mycelium, granular (pasty) } \\
\text { texture and wavy edges. } \\
\text { Central brown sclerotia }\end{array}$ & $\begin{array}{l}\text { Sparse dark cream and } \\
\text { plush mycelium. Scatte- } \\
\text { red brown sclerotia }\end{array}$ \\
\hline
\end{tabular}

Table 2. Rizoctonia solani isolates and cultural characteristics identified in this study.

\begin{tabular}{|l|c|c|c|c|c|c|}
\hline Isolate * & $\begin{array}{c}\text { Location of } \\
\text { collection }\end{array}$ & Potato variety & $\begin{array}{c}\text { Mycelial growth rate } \\
\text { (mm/day) } * * *\end{array}$ & $\begin{array}{c}\text { Nuclei } \\
\text { number } \\
* * *\end{array}$ & $\begin{array}{c}\text { Hyphal width-length } \\
\mu m * * *\end{array}$ \\
\hline RsPN-400 & Pasto & $\begin{array}{c}\text { S. tub. G. Phureja } \\
\text { (Criolla amarilla) }\end{array}$ & 3 & $18.13 \pm 0.09 \mathrm{a}$ & $7.3 \pm 0.3 \mathrm{a}$ & $\begin{array}{c}10.1 \pm 1.0 \mathrm{a} \\
108.9 \pm 13.9 \mathrm{a}\end{array}$ \\
\hline
\end{tabular}


BETANCOURTH-GARCIA / CASTRO-CAICEDO / QUIROZ-OJEDA / SAÑUDO-SOTELO /

FLOREZ-CASANOVA / SALAZAR-GONZALEZ

Table 2. Rizoctonia solani isolates and cultural characteristics identified in this study.

\begin{tabular}{|c|c|c|c|c|c|c|}
\hline Isolate * & $\begin{array}{l}\text { Location of } \\
\text { collection }\end{array}$ & Potato variety & Group ** & $\begin{array}{l}\text { Mycelial growth rate } \\
(\mathrm{mm} / \mathrm{day}) * * *\end{array}$ & $\begin{array}{c}\text { Nuclei } \\
\text { number }\end{array}$ & $\begin{array}{l}\text { Hyphal width-length } \\
\mu \mathrm{m}\end{array}$ \\
\hline RsPN-232 & Pasto & $\begin{array}{l}\text { S. tub. G. Phureja } \\
\text { (Puerreña) }\end{array}$ & 13 & $16.87 \pm 0.16$ abcde & $6.3 \pm 0.4$ & $8.5 \pm 0.7$ a $99.9 \pm 13.6$ \\
\hline RsPN-135 & Pasto & $\begin{array}{c}\text { S. tuberosum } \\
\text { (Parda Suprema) }\end{array}$ & 9 & $16.84 \pm 0.27$ abcde & $5.7 \pm 0.3$ & $8.8 \pm 0.5$ a $82.9 \pm 6.3$ \\
\hline RsPN-183 & Pasto & $\begin{array}{l}\text { S. tuberosum } \\
\text { (Diacol Capiro) }\end{array}$ & 13 & $16.80 \pm 0.27$ abcde & $5.3 \pm 0.6$ & $9.9 \pm 0.3$ a $93.4 \pm 5.0$ \\
\hline RsPN-109 & Pasto & $\begin{array}{l}\text { S. tuberosum } \\
\text { (Única) }\end{array}$ & 1 & $16.65 \pm 0.20$ abcde & $6.7 \pm 0.8$ & $8.8 \pm 0.5$ a $105.8 \pm 9.4$ \\
\hline RsPN-195 & Pasto & $\begin{array}{l}\text { S. tuberosum } \\
\text { (Diacol Capiro) }\end{array}$ & 1 & $16.60 \pm 0.09$ abcde & $6.6 \pm 0.4$ & $9.5 \pm 0.9$ a $90.4 \pm 12.0$ \\
\hline RsPN-325 & Pasto & $\begin{array}{l}\text { S. tuberosum } \\
\text { (Superior) }\end{array}$ & 2 & $16.58 \pm 0.11 \mathrm{abcde}$ & $5.8 \pm 0.1$ & $8.1 \pm 0.7$ a $72.7 \pm 2.5$ \\
\hline RsPN-158 & Pasto & $\begin{array}{l}\text { S. tuberosum } \\
\text { (Diacol Capiro) }\end{array}$ & 11 & $15.99 \pm 0.35$ bcde & $6.5 \pm 0.4$ & $10.5 \pm 1.3$ a $102.9 \pm 3.2$ \\
\hline RsPN-175 & Pasto & $\begin{array}{l}\text { S. tuberosum } \\
\text { (Diacol Capiro) }\end{array}$ & 8 & $14.98 \pm 0.96 \mathrm{e}$ & $6.4 \pm 0.5$ & $8.1 \pm 0.1$ a $118.4 \pm 18.9$ \\
\hline RsPN-24 & Ipiales & $\begin{array}{l}\text { S. tuberosum } \\
\text { (Diacol Capiro) }\end{array}$ & 5 & $16.94 \pm 0.22$ abcde & $7.2 \pm 1.0$ & $7.9 \pm 0.2$ a $74.1 \pm 1.7$ \\
\hline RsPN-7 & Ipiales & $\begin{array}{l}\text { S. tub. G. Phureja } \\
\text { (SuaPa) }\end{array}$ & 11 & $16.88 \pm 0.13$ abcde & $8.2 \pm 0.8$ & $8.3 \pm 0.6$ a $94.3 \pm 8.9$ \\
\hline RsPN-346 & Ipiales & $\begin{array}{l}\text { S. tub. G Phureja } \\
\text { (Ocarina) }\end{array}$ & 15 & $16.76 \pm 0.15$ abcde & $6.3 \pm 0.6$ & $8.1 \pm 0.6$ a $106.3 \pm 11.5$ \\
\hline RsPN-345 & Ipiales & $\begin{array}{l}\text { S. tuberosum } \\
\text { (Diacol Capiro) }\end{array}$ & 15 & $16.53 \pm 0.42$ abcde & $7.0 \pm 0.4$ & $8.2 \pm 0.2$ a $96.4 \pm 1.4$ \\
\hline RsPN-374 & Ipiales & $\begin{array}{l}\text { S. tuberosum } \\
\text { (Diacol Capiro) }\end{array}$ & 3 & $16.46 \pm 0.26$ abcde & $8.0 \pm 1.3$ & $7.4 \pm 0.2$ a $104.9 \pm 14.1$ \\
\hline RsPN-3 & Ipiales & $\begin{array}{l}\text { S. tuberosum } \\
\text { (Superior) }\end{array}$ & 10 & $16.28 \pm 0.25$ abcde & $6.1 \pm 0.2$ & $11.2 \pm 0.8 \mathrm{a} 88.7 \pm 12.9$ \\
\hline RsPN-36 & Tuquerres & $\begin{array}{l}\text { S. tuberosum } \\
\text { (Roja Huila) }\end{array}$ & 6 & $17.66 \pm 0.20 \mathrm{abc}$ & $6.4 \pm 0.3$ & $7.4 \pm 0.1$ a $114.2 \pm 12.1$ \\
\hline RsPN-274 & Tuquerres & $\begin{array}{l}\text { S. tuberosum } \\
\text { (Diacol Capiro) }\end{array}$ & 6 & $18.09 \pm 0.16 a$ & $5.8 \pm 0.4$ & $7.8 \pm 0.4$ a $75.0 \pm 3.7$ \\
\hline RsPN-269 & Tuquerres & $\begin{array}{l}\text { S. tuberosum } \\
\text { (Diacol Capiro) }\end{array}$ & 8 & $17.07 \pm 0.15 \mathrm{abcd}$ & $6.3 \pm 0.7$ & $9.2 \pm 0.8$ a $92.6 \pm 6.3$ \\
\hline RsPN-262 & Tuquerres & $\begin{array}{l}\text { S. tuberosum } \\
\text { (Diacol Capiro) }\end{array}$ & 5 & $16.98 \pm 0.11 \mathrm{abcd}$ & $4.9 \pm 0.2$ & $7.9 \pm 0.3$ a $101.6 \pm 2.3$ \\
\hline RsPN-290 & Tuquerres & $\begin{array}{l}\text { S. tuberosum } \\
\text { (Diacol Capiro) }\end{array}$ & 4 & $16.94 \pm 0.02$ abcde & $6.2 \pm 0.8$ & $12.9 \pm 4.9$ a $91.0 \pm 19.6$ \\
\hline RsPN-99 & Tuquerres & $\begin{array}{l}\text { S. tuberosum } \\
\text { (Única) }\end{array}$ & 12 & $15.79 \pm 0.23$ cde & $5.9 \pm 0.3$ & $7.8 \pm 0.5$ a $84.1 \pm 5.7$ \\
\hline RsPN-289 & Tuquerres & $\begin{array}{l}\text { S. tuberosum } \\
\text { (Diacol Capiro) }\end{array}$ & 12 & $12.43 \pm 1.34 f$ & $5.2 \pm 0.1$ & $8.7 \pm 0.5$ a $99.2 \pm 5.2$ \\
\hline RsPN-487 & Ospina & $\begin{array}{l}\text { S. tuberosum } \\
\text { (Única) }\end{array}$ & 4 & $17.85 \pm 0.09 a b$ & $6.3 \pm 0.5$ & $8.6 \pm 0.1$ a $95.9 \pm 5.0$ \\
\hline
\end{tabular}

Continued on the next page 
Table 2. Rizoctonia solani isolates and cultural characteristics identified in this study.

\begin{tabular}{|l|c|c|c|c|c|c|}
\hline Isolate * & $\begin{array}{c}\text { Location of } \\
\text { collection }\end{array}$ & Potato variety & Group ** & $\begin{array}{c}\text { Mycelial growth rate } \\
\text { (mm/day) } * * *\end{array}$ & $\begin{array}{c}\text { Nuclei } \\
\text { number }\end{array}$ & $\begin{array}{c}\text { Hyphal width-length } \\
\mu \mathrm{m}\end{array}$ \\
\hline RsPN-469 & Ospina & $\begin{array}{c}\text { S. tuberosum } \\
\text { (Diacol Capiro) }\end{array}$ & 9 & $16.87 \pm 0.14$ abcde & $5.8 \pm 1.0$ & $8.0 \pm 0.6$ a $102.5 \pm 6.8$ \\
\hline RsPN-434 & Ospina & $\begin{array}{c}\text { S. tuberosum } \\
\text { (Diacol Capiro) }\end{array}$ & 14 & $17.31 \pm 0.14$ abc & $7.3 \pm 0.3$ & $8.1 \pm 0.5$ a $77.6 \pm 3.4$ \\
\hline RsPN-484 & Ospina & $\begin{array}{c}\text { S. tuberosum } \\
\text { (Diacol Capiro) }\end{array}$ & 14 & $17.30 \pm 0.17$ abc & $5.8 \pm 0.5$ & $8.4 \pm 0.3$ a $90.5 \pm 3.8$ \\
\hline RsPN-432 & Ospina & $\begin{array}{c}\text { S. tuberosum } \\
\text { (Diacol Capiro) }\end{array}$ & 10 & $17.21 \pm 0.17$ abcd & $6.9 \pm 0.5$ & $8.6 \pm 0.3$ a $86.0 \pm 4.3$ \\
\hline RsPN-482 & Ospina & $\begin{array}{c}\text { S. tuberosum } \\
\text { (Diacol Capiro) }\end{array}$ & 2 & $16.45 \pm 0.14$ abcde & $6.9 \pm 0.8$ & $6.6 \pm 0.1$ a $103.2 \pm 3.5$ \\
\hline RsPN-486 & Ospina & $\begin{array}{c}\text { S. tuberosum } \\
\text { (Única) }\end{array}$ & 7 & $16.34 \pm 0.09$ abcde & $6.7 \pm 0.6$ & $10.0 \pm 0.8$ a $89.2 \pm 2.4$ \\
\hline RsPN-442 & Ospina & $\begin{array}{c}\text { S. tuberosum } \\
\text { (Diacol Capiro) }\end{array}$ & 7 & $15.28 \pm 0.15$ de & $6.5 \pm 0.7$ & $8.4 \pm 0.8$ a $106.5 \pm 8.1$ \\
\hline
\end{tabular}

${ }^{*}$ Isolates encoded: $R$. solani (Rs), potato (P), Nariño (N).

** Groups according cultural preliminary features on PDA (related to Tab. 1).

***Values are mean \pm standard error. Means followed by the same letter in a columns do not differ according to Tukey's test.

Strains pigmentation. During the first $2 \mathrm{~d}$, the colonies formed hyaline mycelium that adhered to the medium, characteristic of $R$. solani populations according to Dubey et al. (2014). In the following days, the mycelium had different pigmentations: white, cream to pale beige. According to the color table (Kramer, 2004), at $8 \mathrm{~d}$-old, pale brown predominated in $50 \%$ of the isolates, with cream in $30 \%$, and the rest had the two colors. At $15 \mathrm{~d}$, pale brown was the predominant color in $26 \%$ of the isolates, with cream in $10 \%$, beige in $10 \%$ and brown in $6.6 \%$ of the isolates. The rest of colonies had similar colors, two were salmon. Several authors (Muzhinji et al., 2015; Abdel-Sattar et al., 2017) have reported that the pigmentation of $R$. solani colonies is a variable characteristic exhibited by isolates from all species of plants affected by this pathogen. It appears to be related to the culture medium, temperature, age, and possibly the genetics of the fungus. In potato isolates, Misawa and Kurose (2018) found white pale brown, slightly gray and brown colors; while Muzhinji et al. (2015) reported $R$. solani isolates in different AG groups, with white to brown mycelium. Oliveira et al. (2014) found colonies with colors from beige to brown. In the present study, this characteristic was probably associated with strain age in the PDA medium.

Strain texture. At $8 \mathrm{~d}$-old, the plush mycelium adhered to the medium in $63.3 \%$ of isolates, as reported by Carling and Leiner (1990). Cottony and raised mycelium was observed in 25\% of the isolates, and the rest had lower proportions of both types. Four isolates had granular texture. After $15 \mathrm{~d}, 94 \%$ of the isolates had plush mycelium adhered to the medium, and the rest of colonies exhibited cottony, sparse, aerial mycelium adhered to the lid of the Petri dish. This last characteristic was not highly variable although several authors have reported colonies with abundant aerial mycelium (Abdel-Sattar et al., 2017; Misawa and Kurose, 2019).

Strain growth pattern. The varied GP initially exhibited colonies, and it changed over time, as reported by Abdel-Sattar et al. (2017). A simple radial pattern had $30 \%$ of isolates at $8 \mathrm{~d}$-old, followed by $13.5 \%$ with a complex radial pattern (several circles). The rest of the isolates had varied forms, such as scattered and star-shaped. At 15 d, $26.6 \%$ of the isolates had complex radial forms, followed by $23.3 \%$ with a simple radial, and the rest exhibited scattered and star forms (Fig. 2). This variability, as reported by Abdel-Sattar et al. (2017) and Misawa and Kurose (2019), coincided in some cases with the formation of simple and multiple concentric circles, changing over time.

Sclerotia characteristics. Sclerotia formation began at $6 \mathrm{~d}$-old in $86 \%$ of the strains, similar to that described by Abdel-Sattar et al. (2017) and Gondal et 
al. (2019), with varying colorations between white, cream and brown, either rough or smooth. Fifteen days later, $35 \%$ of the isolates showed brown sclerotia, followed by beige (25\%) and cream (15\%). The rest were white, cream and orange. Three isolates did not form sclerotia (Fig. 2A). The 27 strains showed varied PSF; $50 \%$ were scattered, $40 \%$ were peripheral, and the rest were central, with a star shape, or combined both star/peripheral (Fig. 2A), similar to the results of Misawa and Kurose (2019). Forty-six percent of the strains were classified with a low sclerotia/ plate (1-100), 42\% were moderate (between $>100$ 200 ), and $11.5 \%$ had abundant sclerotia (> 200) (Fig. $2 \mathrm{~B})$. The size and shape of the sclerotia was variable; macro $(>1 \mathrm{~mm})$ and microsclerotia $(<1 \mathrm{~mm})$, jointly in $90 \%$ of the isolates, with irregular or undefined shapes, and the rest presented microsclerotia with regular borders (Fig. 2C). These results coincide with

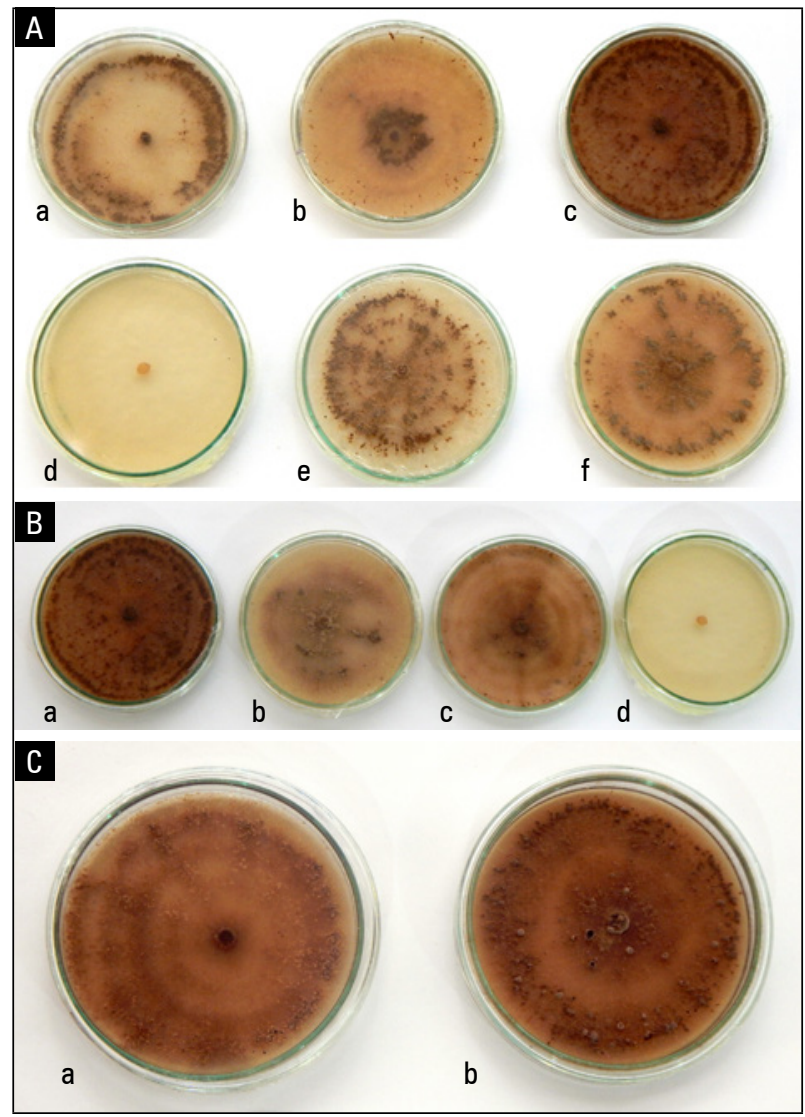

Figure 2. Mycelial growth pattern and sclerotia of $\boldsymbol{R}$. solani on PDA. A) Arrangement, a: peripheral, b: central, c: scattered, d: absent, e: starry and f: starry/peripheral. B) Quantity, a: abundant, b: moderate, c: scarce, d: absent. C) Size, a: microsclerotia, b: macrosclerotia and microsclerotia. those recorded by Dubey et al. (2014), who reported sclerotia diameters between 0.10-5.4 $\mathrm{mm}$ and with a peripheral, central and dispersed arrangement. AbdelSattar et al. (2017) reported the formation of brown sclerotia, $5.0 \mathrm{~mm}$ in diameter, while Escalona et al. (2011) found abundant dark brown sclerotia located only in the center of the colonies, similar to Misawa and Kurose (2019).

Mycelial growth rate. This variable was evaluated during the first $6 \mathrm{~d}$, when all isolates filled the plate. All strains had rapid growth, as observed by Dubey et al. (2014), with a MGR higher of $12 \mathrm{~mm} \mathrm{~d}^{-1}$. Although the ANOVA showed statistical differences $(P<0.0001)$ for the rate of mycelial growth between the isolates, no relationship was observed with the 15 initially determined morphological groups, neither with the geographic location of the cultures nor with the potato variety. According to Tukey's test $(P=0.05)$, only one isolate (RsPN-289) had the lowest MGR with $12.43 \mathrm{~mm} \mathrm{~d}^{-1}$, and the maximum was $18.13 \mathrm{~mm} \mathrm{~d}^{-1}$ (RsPN-400) (Tab. 2). Escalona et al. (2011) and Dubey et al. (2014) indicated that the MGR of $R$. solani depends on the culture medium and the incubation temperature. At $10^{\circ} \mathrm{C}$, the full plate can occur between $7-11 \mathrm{~d}$, while, at $20^{\circ} \mathrm{C}$, it occurs in $4 \mathrm{~d}$. At $30^{\circ} \mathrm{C}$, it occurs in $16 \mathrm{~d}$. In our study, the full of plate was in $6 \mathrm{~d}$ at $25^{\circ} \mathrm{C}$. However, the MGR may be related to AG groups or pathogenicity level, aspects that will be addressed to the next phase of the research.

Microscopic characterization. All isolates showed the typical characteristics of $R$. solani: hyphae with

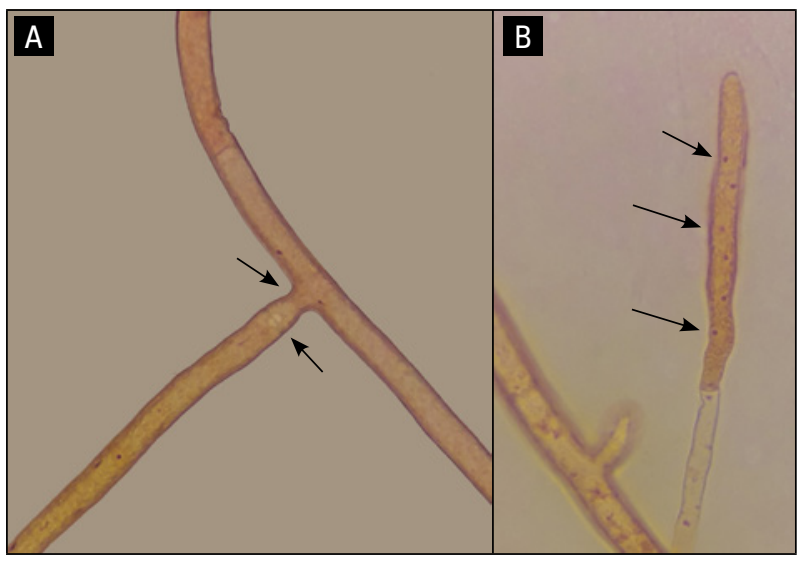

Figure 3. Typical features of $\boldsymbol{R}$. solani under light microscope (100X). A) septate hypha with right-angle branch, constriction at the point of branching and septum close to the origin. B) Formation of multiple nuclei. 
right-angle branches, branches at the distal septae of cells, dolipore septa, constriction at the junction of these hyphae, and multinucleate cells (Fig. $3 \mathrm{~A}$ and B), as described by Dubey et al. (2014) and Abdel-Sattar et al. (2017). No statistical differences were found in hyphae dimensions; the width ranged between 6.6 and $12.9 \mu \mathrm{m}$ (average $8.7 \mu \mathrm{m}$ ), and the hyphal distance between two septae varied from 72.7 to $118.4 \mu \mathrm{m}$ (average $95.0 \mu \mathrm{m}$ ) (Tab. 2). These values are similar to those reported by Dubey et al. (2014) -4.1-10.3 $\mu \mathrm{m}$-, who found some isolates with values of $>8$ in the groups AG1 to AG5. No differences were found in nuclei number, with a minimum of 4.9 and maximum of 8.2 , within the ranges reported by Tsror (2010) and Misawa and Kurose (2019) with (4.4-10.9 nuclei).

\section{Pathogenicity tests}

Thirty-five days after inoculation, some plants showed secondary symptoms, such as yellowing, wilting and reduction of plant development, as compared to the control (Fig 4A). Reduction of root area, necrotic lesions in root tips and sections, in stolons

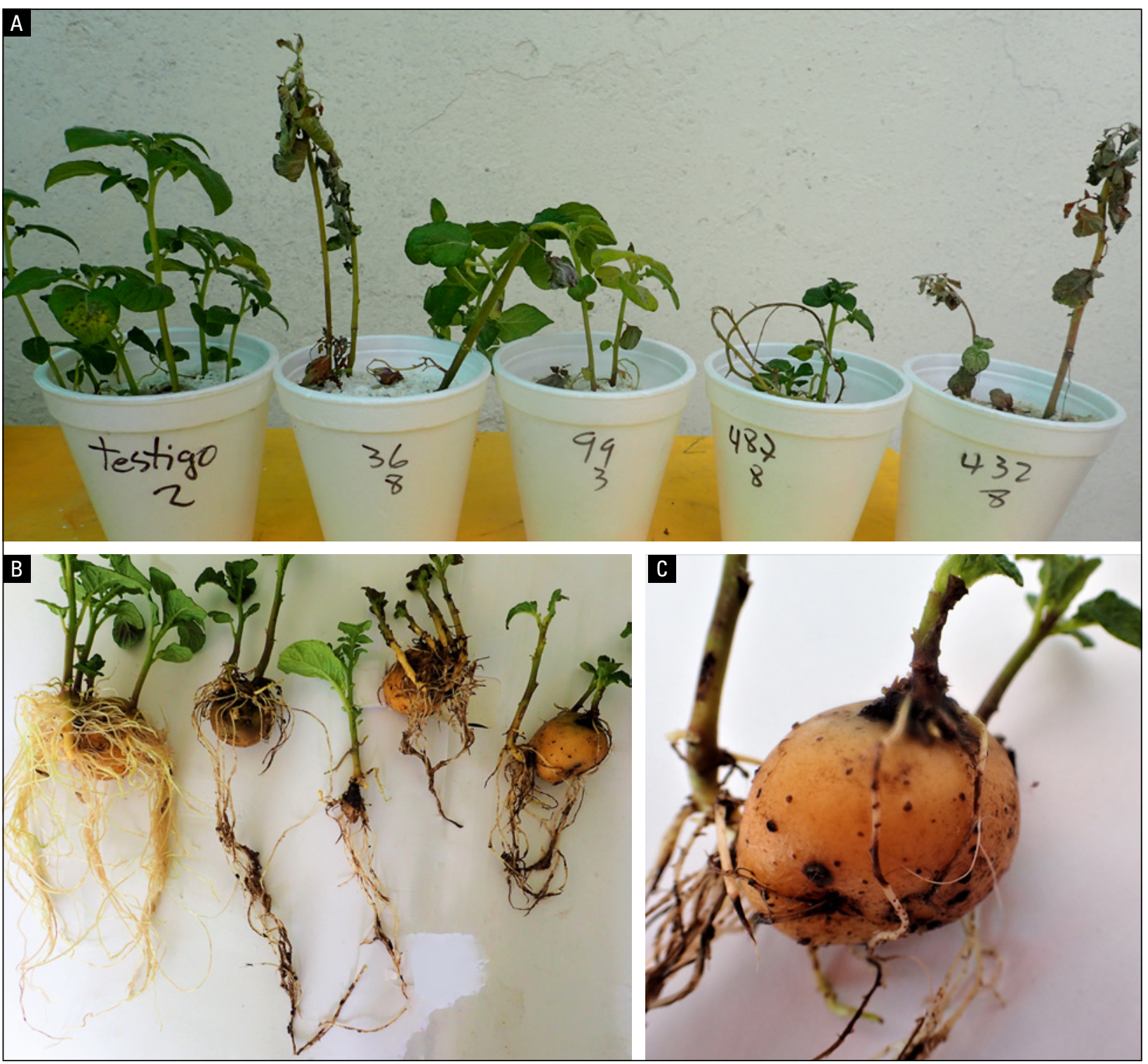

Figure 4. Symptoms caused by different strains of $R$. solani in potato seedlings (S. tuberosum Group Phureja). A-B) Secondary symptoms and reduction of roots, as compared to the control (far left), and C) Necrotic lesions on roots. 
and in some cases in shoot tissues were observed (Fig. 4 B and C). Out of 30 isolates, 24 caused root lesions in $100 \%$ of the plants, as well as reduction of more than $50 \%$ of roots, as compared with the control, coinciding with symptoms mentioned by several authors (Abdel-Sattar et al., 2017). These 24 isolates produced some small sclerotia on developing tubers (12.5-100\% of plants). Six isolates caused both secondary and primary symptoms (50- $87.5 \%$ of plants). No symptoms of stem canker were observed. External symptoms, mainly plant reduction of development, were related with primary symptoms at the variable level. Colonies of the pathogen were recovered from root lesions. The results showed the susceptibility of the potato variety S. tuberosum Group Phureja in this first stage of plant development. According to Dubey et al. (2014), R. solani is more aggressive in young plants because, in older plants, tissues resist attack. However, new stolons and roots would be re-infected as well as the development of sclerotia in tubers, as observed in the potato crops.

On the other hand, several authors (Dubey et al., 2014; Alban, 2015; Abdel-Sattar et al., 2017) suggested differences in pathogenicity or no infection with different isolates within a population, which is apparently related to the state of the potato crops the isolates come from. Genetic aspects, differences in virulence, and AGs present in populations under natural conditions are also factors mentioned by several authors (Carling, 1996; Das et al., 2014), including differences in pathogenicity level related with AGs on different organs of the plant (roots, stems and tubers). This may explain the lower infection observed with six isolates in this research. It is important to mention the efficacy of the $R$. solani inoculation method, using an enriched natural substrate to multiply this type of soil pathogens, such as parboiled rice (Castro et al., 2013). Several authors (Castro and Rivillas, 2012; Abdel-Sattar et al., 2017; Misawa and Kurose, 2018) suggested other substrates such as wheat, sorghum, carrot, or stems of Typha latifolia, since long-term preservation of the inoculum from mycelium in culture medium would affect fungus infectivity.

Finally, the evaluation of symptoms is a topic for future research because of the ability of $R$. solani to cause multi-symptoms. Preliminary pathogenicity verification of isolates was one of the objectives of the present research. However, studies on genetic diversity and $A G$ groups suggest a greater demand in the inoculation standardization, evaluation methods, and experiment design to determine the incidence and severity of isolates on different stages of plant development (Fiers et al., 2011). This is also true in the case of evaluations under controlled conditions throughout the crop cycle to find the presence of symptoms and signs (mycelium and sclerotia) in roots, stems and tubers, as suggested by Alban (2015) and Misawa and Kurose (2018). This will allow greater precision in results that determine the presence of pathogenic populations under field conditions.

\section{CONCLUSION}

The presence of $R$. solani was verified in all potato producing areas in the Department of Nariño.

Rhizoctonia solani could be isolated from different potato varieties of $S$. tuberosum and $S$. tuberosum Group Phureja.

The $R$. solani isolates showed morphological variability in terms of color, texture and colony growth pattern.

Variability was also noticed in the production and characteristics of the sclerotia and mycelial growth rate.

For the variability of $R$. solani, all isolates were pathogenic, indicating their ability to cause damage in crops.

Conflict of interests: The manuscript was prepared and reviewed with the participation of the authors, who declare that there exists no conflict of interest that puts at risk the validity of the presented results.

\section{BIBLIOGRAPHIC REFERENCES}

Abdel-Sattar, M., H. El-Marzouky, and U.E. Ibrahim. 2017. Test and anastomosis group of Rhizoctonia solani the causal organism of stem canker and black scurf disease of potato in Egypt. J. Appl. Plant Prot. 6(1), 1-8. Doi: 10.21608/japp.2017.7494

Alban, M.A.P. 2015. Identificación, aislamientos, caracterización y evaluación de la capacidad de infección en tubérculos de Rhizoctonia solani de suelos paperos en la Provincia del Carchi. Undergraduate thesis. Universidad de las Fuerzas Armadas, Sangolqui, Ecuador.

Álvarez-Sánchez, D., A. Hurtado-Benavides, D. Chaves-Morillo, and D. Andrade-Díaz. 2018. Actividad biocida del aceite esencial de Lippia origanoides H.B.K. 
(Verbenaceae) sobre Rhizoctonia solani: in vitro. Rev. Colomb. Cienc. Hortic. 12(3), 668-676. Doi: 10.17584/ rcch.2018v12i3.7801

Atkinson, D., M. Thornton, and J. Miller. 2010. Development of Rhizoctonia solani on stems, stolons and tubers of potatoes. I. Effect of inoculum source. Am. J. Potato Res. 87, 374-381. Doi: 10.1007/s12230-010-9143-6

Bandoni, R.J. 1979. Safranin-O as a rapid nuclear stain for fungi. Mycologia (71), 873-874. Doi: 10.1080/00275514.1979.12021088

Carling, D. 1996. Grouping in Rhizoctonia solani by hyphal anastomosis interactions. pp. 37-47. In: Senh, B., S. Jabaji- Hare, S. Neate, and G. Dijst (eds.). Rhizoctonia species: taxonomy, molecular biology, ecology, pathology, and disease control. Kluwer Academic Publishers, Dordrecht, The Netherlands. Doi: 10.1007/978-94-017-2901-7_3

Carling, D.E. and R.H. Leiner. 1990. Virulence of isolates of Rhizoctonia solani AG-3 collected from potato plants and soil. Plant Dis. 74, 901-903. Doi: 10.1094/ PD-74-0901

Castro, C.B.L., A.J. Carreño, N.F. Galeano, X.J. Roux, J.M. Wingfield, and A.L. Gaitán. 2013. Identification and genetic diversity of Rosellinia spp. associated with root rot of coffee in Colombia. Australas. Plant Pathol. 42, 515-523. Doi: 10.1007/s13313-013-0205-3

Castro, A. and C. Rivillas. 2012. Trichoderma spp.: Modos de acción, eficacia y usos en el cultivo de café. Bol. Téc. Cenicafé 38. Fedecafe, Chinchina, Colombia.

Chañag, H.A., S.L. Álvarez, L.E. Lagos, and D.M. Burbano-David. 2018. Sensibilidad de aislamientos de Phytophthora infestans procedentes de Solanum tuberosum a tres fungicidas sistémicos. Rev. Colomb. Cienc. Hortic. 12(3), 592-601. Doi: 10.17584/rcch.2018v12i3.7859

Das, S., F.A. Shah, R.C. Butler, R.E. Fallon, A. Stewart, S. Raikar, and A.R. Pitman. 2014. Genetic variability and pathogenicity of Rhizoctonia solani associated with black scurf of potato in New Zealand. Plant Pathol. 63, 651-666. Doi: 10.1111/ppa.12139

Dubey, S.C., A. Tripathi, B.K. Upadhyay, and U.K. Deka. 2014. Diversity of Rhizoctonia solani associated with pulse crops in different agro-ecological regions of India. World J. Microbiol. Biotechnol. 30, 1699-1715. Doi: 10.1007/s11274-013-1590-z

Escalona, Y., D. Rodríguez, and A. Hernández. 2011. Rhizoctonia solani Kühn aislado de papa (Solanum tuberosum L.) en los estados Táchira, Mérida, Trujillo y Lara. I. Caracterización cultural. Bioagro 23(3), 161-168.

FEDEPAPA, Federación Colombiana de Productores de Papa. 2019. Nariño. Bol. Reg. 3. Bogota.

Ferrucho, R., P. Ceresini, U. Ramirez, A. McDonald, A. Cubeta, and C. García-Domínguez. 2013. The population genetic structure of Rhizoctonia solani AG-3PT from potato in the Colombian Andes. Phytopathology 103(8), 862-869. Doi: 10.1094/PHYTO-11-12-0278-R

Ferrucho, R.L., J.M. Cifuentes, P. Ceresini, and C. García-Domínguez. 2012. Rhizoctonia solani AG-3PT is the major pathogen associated with potato stem canker and black scurf. Agron. Colomb. 30(2), 204-213.

Fiers, M., V. Edel-Hermann, N. Gautheron, C. Chatot, Y. Hingrat, K. Bouchek-Mechiche, and C. Steinberg. 2011. Genetic diversity of Rhizoctonia solani associated with potato tubers in France. Mycologia 103(6), 12301244. Doi: $10.3852 / 10-231$

Gondal, A.S., A. Rauf, and F. Naz. 2019. Anastomosis Groups of Rhizoctonia solani associated with tomato foot rot in Pothohar Region of Pakistan. Sci. Rep. 9, 3910. Doi: 10.1038/s41598-019-40043-5

ICA, Instituto Colombiano Agropecuario. 2011. Manejo fitosanitario del cultivo de la papa (Solanum tuberosum subsp. Andigena y S. phureja) -Medidas para la temporada invernal. Bogota.

Kramer, L.A. 2004. The online auction color chart: the new language of color for buyers and sellers. Online Auction Color Chart Co., Palo Alto, CA.

Misawa, T. and D. Kurose. 2018. First report of binucleate Rhizoctonia AG U causing black scurf on potato tubers in Japan. New Dis. Rep. 38, 24. Doi: 10.5197/j.2044-0588.2018.038.024

Misawa, T. and D. Kurose. 2019. Anastomosis group and subgroup identification of Rhizoctonia solani strains deposited in NARO Genebank, Japan. J. Gen. Plant Pathol. 85, 282-294. Doi: 10.1007/s10327-019-00848-8

Misawa, T., D. Kurose, N. Mori, and T. Toda. 2018. Characterization of Japanese Rhizoctonia solani AG-2-1 isolates using rDNA-ITS sequences, culture morphology, and growth temperature. J. Gen. Plant Pathol. 84, 387394. Doi: $10.1007 / \mathrm{s} 10327-018-0808-1$

Muzhinji, N., M. Truter, J.W. Woodhall, and J.E. van der Waals. 2015. Anastomosis groups and pathogenicity of Rhizoctonia solani and binucleate Rhizoctonia from potato in South Africa. Plant Dis. 99, 1790-1802. Doi: 10.1094/PDIS-02-15-0236-RE

Oliveira, A.C., P.E. Souza, E.A. Pozza, A.D.R. Fugueira, G.D. Avelar, E.A. Gomez, and F.P. Monteiro. 2014. Caracterização morfológica, genética e patogenicidade de isolados de Rhizoctonia solani provenientes de algodoeiros no Brasil. Biosci. J. 30(5), 512-524.

Sneh, B., L. Burpee, and A. Ogoshi. 1991. Identification of Rhizoctonia solani species. APS Press, Saint Paul, MN.

Tsror, L. 2010. Biology, epidemiology and management of Rhizoctonia solani on potato. J. Phytopathol. 158, 649658. Doi: 10.1111/j.1439-0434.2010.01671.x

Zhan, J. 2016. Population genetics of plant pathogens. eLS; John Wiley \& Sons, Chichester, UK. Doi: 10.1002/9780470015902.a0021269.pub2 